\title{
Peran Homeschooling dalam Mengembangkan Kecerdasan Spiritual Anak (Penelitian di Rumah Negla, Desa Neglasari, Kota Banjar)
}

\author{
Nina Mariana \\ Institut Agama Islam Darussalam (IAID) Ciamis \\ Email: nina.marianabjr@gmail.com \\ S. Koswara \\ Program Pascasarjana, Institut Agama Islam Darussalam (IAID) Ciamis \\ Email: skoswara.iaid@gmail.com
}

Received: March 6, 2018 | Accepted: September 12, 2018

\begin{abstract}
This study aims to explore the role of homeschooling in developing children's spiritual intelligence. This research uses descriptive analysis method. The research site is in Rumah Negla, Desa Neglasari Village, Kota Banjar. Data collected through interviews, observations, and document review. Research respondents consisted of organizers of homeschooling education, parents of students, as well as other parties involved in organizing homeschooling, both directly and indirectly. This field research in education has found several conclusions. First, to optimize children's spiritual intelligence, homeschool organizers make systematic and measurable plans. In the planning, homeschool managers try to use children's psychology theories, developmental psychology, and learning models and strategies. Second, homeschooling education activities are carried out by developing a comfortable, pleasant learning environment, playing while learning, training, introducing the values of noble and religious characters.
\end{abstract}

\begin{abstract}
Abstrak
Penelitian ini bertujuan untuk mendalami peran homeschooling dalam mengembangkan kecerdasan spiritual anak. Penelitian ini menggunakan metode deskriptif analisis. Tempat penelitian di Rumah Negla, Desa Neglasari, Kota Banjar. Data dikumpulkan melalui wawancara, pengamatan, dan kajian dokumen. Responden penelitian terdiri atas penyelenggara pendidikan homeschooling, orang tua siswa, serta pihak-pihak lain yang terlibat dalam penyelenggaraan homeschooling, baik secara langsung maupun tidak langsung. Penelitian lapangan di bidang pendidikan ini berhasil menemukan beberapa kesimpulan. Pertama, untuk mengoptimalkan kecerdasan spiritual anak, penyelenggara homeschooling membuat perencanaan yang sistematis dan terukur. Dalam perencanaan itu, pengelola homeschooling berusaha untuk menggunakan teori-teori psikologi anak, psikologi perkembangan, serta model-
\end{abstract}


model dan strategi pembelajaran. Kedua, kegiatan pendidikan homeschooling dilakukan dengan mengembangkan suasana belajar yang nyaman, menyenangkan, belajar sambil bermain, latihan ringan, hingga mengenalkan nilai-nilai karakter luhur dan religius.

\section{Keywords}

Islamic education, homeschooling, spiritual intelligence

\section{Pendahuluan}

Anak adalah manusia kecil dengan potensi yang harus senantiasa dikembangkan. Anak memiliki karakteristik tertentu yang khas dan tidak sama dengan orang dewasa. Anak selalu bergerak aktif, dinamis, antusias dan ingin tahu terhadap apa yang dilihat, didengar, serta dirasakannya. Mereka seolaholah tidak pernah berhenti bereksplorasi dan belajar. Anak memiliki karakter egosentris, rasa ingin tahu secara alamiah, makhluk sosial, unik, kaya dengan fantasi, memiliki daya perhatian yang pendek dan masa yang paling potensial untuk belajar (Pangastuti, 2014, p. 15).

Di dalam konteks pendidikan anak, terdapat dua ruang yang bisa dimanfaatkan untuk mengembangkan potensi anak, yaitu sekolah formal dan kultural. Sekolah formal berorientasi pada nilai laporan pendidikan (kepentingan sekolah), bukannya mengedepankan keterampilan hidup dan bersosial (nilai-nilai iman dan moral). Di sekolah, banyak murid mengejar nilai laporan pendidikan dengan mencontek atau membeli ijazah palsu. Selain itu, perhatian secara personal pada anak kurang diperhatikan. Ditambah lagi identitas anak distigmatisasi dan ditentukan oleh teman-temannya yang lebih pintar, lebih unggul, atau lebih cerdas. Keadaan demikian menambah suasana sekolah menjadi tidak menyenangkan (Sumardiono, 2007, p. 28)

Dalam pandangan Simbolon, sebagaimana dikutip Ariefianto, homeschooling berkembang $\mathrm{di}$ Indonesia terjadi akibat dari rasa ketidakpercayaan terhadap sekolah formal karena kurikulum terus berubah (ganti menteri ganti kurikulum) dan dirasakan memberatkan peserta didik, terdapat pula anggapan anak sebagai objek bukan subjek, memasung kreativitas dan kecerdasan anak, baik segi emosional, moral, maupun spiritual. Bila ditelaah lebih jauh banyak faktor yang dapat mempengaruhi beralihnya anakanak dari sistem sekolah formal ke homeschooling, diantaranya yang tidak kalah pentingnya adalah kekhawatiran orang tua terhadap anak- anak dari 
lingkungan luar yang negatif serta adanya ketidakpuasan orang tua terhadap sistem sekolah formal (Ariefianto, 2017, p. 22)

Ketidakpuasan tersebut semakin memicu orang tua memilih mendidik anak-anaknya di rumah, namun dengan resiko harus meluangkan banyak waktu dan tenaga. Homeschooling menjadi tempat harapan orang tua untuk meningkatkan mutu pendidikan anak-anak, mengembangkan nilai-nilai iman/agama dan moral, serta mendapatkan suasana belajar yang menyenangkan (Sumardiono, 2007, p. 28).

Homeschooling (Sekolah Rumah) saat ini mulai menjadi salah satu model pilihan orang tua dalam mengarahkan anak-anaknya dalam bidang pendidikan. Pilihan ini muncul karena adanya pandangan orang tua tentang kesesuaian minat oleh anak-anaknya. Homeschooling ini banyak dilakukan di kota besar, terutama oleh mereka yang pernah melakukannya ketika berada di luar negeri. Di Indonesia, keberadaan homeschooling sudah mulai menjamur di Jakarta dan kota-kota besar lainnya. Untuk tahap pertama, keberadaan proses belajar dan mengajar model rumahan ini belum menuai minat dari khalayak umum (Sumardiono, 2007, p. 28)

\section{Kajian Teori}

Menurut Omar Muhammad al-Touny al-Syaibani, pendidikan Islam diartikan sebagai "usaha mengubah tingkah laku individu dalam kehidupan pribadinya atau kehidupan kemasyarakatan dan kehidupan dalam alam sekitarnya melalui proses kependidikan." Perubahan itu dilandasi dengan nilai-nilai yang diserap dari ajaran agama Islam. Jelaslah bahwa proses kependidikan merupakan rangkaian usaha membimbing dan mengarahkan potensi hidup manusia yang berupa kemampuan-kemampuan dasar dan kemampuan belajar, sehingga terjadilah perubahan dalam kehidupan pribadinya sebagai makhluk individual dan sosial, serta dalam hubungannya dengan alam dan lingkungan social di sekitarnya. Proses tersebut senantiasa berada dalam nilai-nilai islami, yaitu nilai-nilai yang melahirkan norma-norma syarīah dan akhlaq al-karimah (Arifin, 2003, p. 15).

Hasil rumusan Seminar Pendidikan Islam se-Indonesia tahun 1960, memberikan pengertian Pendidikan Islam "Sebagai bimbingan terhadap pertumbuhan rohani dan jasmani menurut ajaran Islam dengan hikmah untuk mengarahkan, mengajarkan, melatih, mengasuh dan mengawasi berlakunya semua ajaran Islam.” Istilah membimbing, mengarahkan, mengasuh, mengajarkan, atau melatih mengandung pengertian usaha mempengaruhi jiwa anak didik melalui proses bertahap menuju tujuan yang ditetapkan (Arifin, 2003, p. 15). 
Dalam pandangan filosofis pendidikan, metode merupakan alat yang dipergunakan untuk mencapai tujuan. Alat tersebut mempunyai fungsi ganda, yaitu bersifat polipragmatis dan monopragmatis. Sebuah metode disebut polipragmatis bilamana metode itu mengandung kegunaan yang serba ganda. Suatu metode tertentu pada suatu situasi dan kondisi tertentu dapat dipergunakan untuk merusak, namun pada situasi kondisi yang lain dapat digunakan untuk membangun atau memperbaiki (Arifin, 2003, p. 89). Sementara metode disebut monopragmatis apabila alat yang dipergunakan hanya berfungsi untuk mencapai suatu macam tujuan saja. Hanya saja, bagaimanapun bentuk dan kemampuan suatu metode, penggunaan suatu metode dalam proses pendidikan adalah mutlak (Arifin, 2003, p. 90).

Dalam proses kependidikan, tujuan akhir merupakan tujuan umum atau tujuan tertinggi yang hendak dicapai. Untuk mencapai tujuan itu diperlukan berbagai komponen tujuan yang akan dijadikan sarana untuk mencapai tujuan akhir tersebut (Arifin, 2003, p. 114). Oleh karena suatu tujuan akhir merupakan kristalisasi nilai-nilai yang ingin diwujudkan dalam pribadi anak didik, maka tujuan akhir itu harus meliputi semua aspek yang terintegrasi dalam pola kepribadian ideal yang bulat dan utuh (Arifin, 2003, pp. 114-115).

Secara teoritis, tujuan dapat dibedakan menjadi, pertama, tujuan normatif. Suatu tujuan bersifat normatif jika tujuan yang harus dicapai dilandaskan pada kaidah-kaidah (norma-norma) yang mampu mengkristalisasikan nilai-nilai yang ingin diinternalisasikan. Tujuan ini mencakup: 1) Tujuan formatif, yaitu tujuan yang bersifat memberikan persiapan dasar yang korektif; 2) Tujuan selektif, yaitu tujuan yang bersifat memberikan kemampuan untuk membedakan hal-hal yang benar dan yang salah; 3) Tujuan integratif, yaitu tujuan yang bersifat memberikan kemampuan untuk memadukan fungsi psikis (penyerapan terhadap rangsangan pelajaran, pikiran, perasaan, kemauan, ingatan dan nafsu) ke arah tujuan akhir proses kependidikan; 4) Tujuan determinatif, yaitu tujuan yang bersifat memberikan kemampuan untuk mengarahkan diri kepada sarana-sarana yang sejalan dengan proses kependidikan (Arifin, 2003, p. 115).

\section{Konsep Homeschooling}

Homeschooling berasal dari dari akar kata home dan school. Menurut kamus bahasa Inggris homeschooling merupakan bentuk kata kerja, homeschooling is to instruct (a pupil, for example) in an educational program outside of established schools, especially in the home. Homeschooling berarti membimbing (misalnya: seorang murid) dalam program pendidikan di luar sekolah umum, khususnya dilaksanakan di rumah (Dictionary, 2018). Sementara menurut Ismail, banyak istilah yang digunakan untuk menyebutkan homeschooling. Ada home education dan home-based learning/home-based 
education. Home education merupakan pendidikan bagi anak yang dilaksanakan di rumah, tidak seperti sekolah umum baik negeri/swasta, jenis pendidikan ini biasanya dilaksanakan dengan menitikberatkan peran orang tua atau pembimbing (Ismail, 2016, p. 102)

Dalam bahasa Indonesia, terjemahan yang biasanya digunakan untuk homeschooling adalah "sekolah rumah." Istilah ini dipakai secara resmi oleh Departemen Pendidikan Nasional (Depdiknas) untuk menyebutkan homeschooling. Selain sekolah rumah, homeschooling kadang-kala juga diterjemahkan dengan istilah "sekolah mandiri." Tapi pengistilahan bukanlah sebuah isu yang utama. Bagaimanapun pengistilahannya, esensi homeschooling terpetak pada model pendidikan alternatif selain disekolah. Homeschooling dipraktikkan oleh jutaan keluarga diseluruh dunia. Walaupun ada keinginan untuk membuat sebuah definisi mengenai apa yang dimaksud dengan homeschooling, tetapi tidak mudah untuk melakukannya (Sumardiono, 2007, pp. 3-4).

Dalam Sistem Pendidikan Nasional, penyelenggaraan homeschooling didasarkan pada Undang-Undang Republik Indonesia Nomor 20 Tahun 2003 tentang Sistem Pendidikan Nasional (UU Sisdiknas No 20/2003), Pasal 1, ayat 1 yang berbunyi, "Pendidikan adalah usaha sadar dan terencana untuk mewujudkan suasana belajar dan proses pembelajaran agar peserta didik secara aktif mengembangkan potensi dirinya untuk memiliki kekuatan spiritual keagamaan, pengendalian diri, kepribadian, kecerdasan, akhlak mulia, serta keterampilan yang diperlukan dirinya,masyarakat, bangsa dan negara" (Mulyadi, 2007, pp. 33-34).

Sebagai salah satu alternatif model pendidikan, homeschooling memberikan peluang seluas-luasnya kepada pesertanya untuk mengembangkan diri dan memilih akses terbaik untuk memenuhi "kehausan" mereka terhadap materi pendidikan. Homeschooling menjadi konsep alternatif yang layak diterapkan untuk memberi pilihan terhadap setiap orang untuk menguasai pengetahuan sesuai dengan gaya mereka masing-masing. Namun demikian, informasi seputar model pendidikan homeschooling memang belum memadai diserap masyarakat. Maka, masuk akal jika kemudian sebagian masyarakat menganggap homeschooling sebagai metode pendidikan yang absurd, karena tidak memiliki standar penilaian yang baku dan sistematis (Kembara, 2007, p. 27).

Pada perkembangannya, para pegiat homeschooling terus berusaha menyempurnakan konsep ini, yakni dengan merespons perkembangan kebutuhan akan pendidikan di masyakarat. Semakin banyaknya orang tua yang mantap memilih homeschooling sebagai alternatif pendidikan untuk anakanaknya, mengharuskan homeschooling untuk terus merumuskan parameter- 
parameternya tersendiri. Saat ini, setidaknya ada tiga jenis homeschooling yang berkembang di masyarakat. Masing-masing tipe memiliki keunggulan dan kelemahannya tersendiri (Kembara, 2007, p. 30). Pertama, homeschooling tunggal, yaitu format sekolah rumah yang dilaksanakan oleh orang tua dalam satu keluarga yang dalam pelaksanaannya tidak terintegrasi dengan keluarga lainnya.

Format sekolah rumah tunggal biasanya dipilih oleh keluarga yang ingin memiliki fleksibilitas maksimal dalam penyelenggaraan homeschooling. Mereka bertanggung jawab sepenuhnya atas seluruh proses yang ada dalam homeschooling, mulai perencanaan, pelaksanaan, evaluasi, administrasi, hingga penyediaan sarana pendidikan. Dalam format ini, keluarga biasanya menggunakan fasilitas keluarga atau sarana-sarana umum sebagai penunjang kegiatan belajar peserta didiknya. Format sekolah rumah ini memiliki kompleksitas tinggi, karena seluruh beban atau tanggungjawab berada di tangan keluarga. Walaupun keluarga dapat menggunakan sistem pendukung (support system) apapun yang ada, semua inisiatif berada di ranah kebijakan keluarga (Sumardiono, 2007, p. 60).

Kedua. homeschooling majemuk. Tipe homeschooling kedua ini satu tingkat di atas homeschooling tunggal dalam hal pelibatan indvidu lainnya. Homeschooling majemuk atau lebih dari satu dilaksanakan oleh dua atau lebih keluarga untuk kegiatan tertentu, sementara kegiatan pokok tetap dilaksanakan oleh orang tua masing-masing. Keluarga-keluarga yang memutuskan untuk bergabung dalam homeschooling majemuk ini biasanya memiliki kebutuhankebutuhan yang dapat dikompromikan dalam kegiatan bersama. Contohnya, kurikulum, kegiatan olahraga, keahlian musik, kegiatan sosial, dan kegiatan agama. Karena melibatkan peserta didik lainnya, tentu saja proses belajar menjadi dinamis. Insting sosial pada diri anak pun bisa terasah seperti seharusnya (Kembara, 2007, p. 31).

Ketiga, komunitas homeschooling, yaitu gabungan beberapa homeschooling majemuk yang menyusun dan menentukan silabus, bahan ajar, kegiatan pokok, sarana prasarana, hingga jadwal pembelajaran. Mereka yang memilih berkelompok dalam komunitas homeschooling memandang bahwa konsep homeschooling ini lebih terstruktur dan lengkap untuk pendidikan akademik, pembangunan akhlak mulia dan pencapaian hasil belajar. Selain itu, tersedianya fasilitas pembelajaran yang lebih baik. Karakteristik yang khas dari komunitas homeschooling adalah ruang gerak sosialisasi peserta didik lebih luas, tetapi tetap dapat dikendalikan. Dukungan lebih besar karena masing-masing bertanggungjawab untuk saling mengajar sesuai dengan keahlian masingmasing. Tipe homeschooling ini sesuai untuk peserta didik dengan usia sepuluh tahun ke bawah (Kembara, 2007, pp. 32-33). 
Salah satu konsep kunci dari homeschooling adalah pembelajaran yang tidak berlangsung melalui institusi sekolah formal. Konsep ini membawa kita pada konsep yang lebih umum, yaitu konsep belajar otodidak atau belajar mandiri. Dengan mengambil konsep kunci itu, kita mendapati tokoh-tokoh di dalam sejarah Indonesia yang menempuh pembelajaran secara mandiri. Salah satu contoh yang sangat dikenal adalah Agus Salim, Ki Hajar Dewantara dan Buya Hamka.

Agus Salim mendidik anak-anaknya di rumah yang dibantu istrinya. Sejak lahir, anak-anaknya sudah diajak berbicara dalam bahasa Belanda, tutur katanya begitu runut dan tertata, khas orang sekolahan. Kadang dia berbicara dalam bhasa Belanda dan Inggris yang fasih, serta wawasannya yang luas. Bagi yang baru mengenalnya tentu tak akan mengira Bibsy Soenharjo tak pernah mengenyam pendidikan bangku sekolah. Bibsy, yang bernama asli Siti Asiah, adalah lulusan homeschooling sang ayah, Agus Salim. Bibsy kecil tak pernah menimba ilmu di sekolah formal. Ibunya, Zainatun Nahar, mengajar dia membaca, menulis dan berhitung. Ayahnya mengajarkan segala hal, "tidak ada kelas dan jam pelajaran yang mengikat," kata Bibsy. Keputusan Salim itu dianggap aneh oleh kerabat dan tetangganya, karena pada masa itu, anak yang tak bersekolah formal dipandang aneh dan tak wajar. Terlebih lagi, Agus Salim adalah orang terpelajar dan berpendidikan tinggi (Kembara, 2007, p. 39).

Tiap-tiap orang djadi Guru, tiap-tiap rumah djadi Perguruan! Begitu bunyi semboyan yang tertulis dalam salah satu artikel di dalam buku berjudul Karya Ki Hadjar Dewantara, Bagian 1: Pendidikan yang diterbitkan oleh Madjelis Luhur Persatuan Taman Siswa pada tahun 1962. Ide untuk menjadikan rumah sebagai tempat sekolah merupakan bagian dari idealisme pendiri Taman Siswa itu. Ki Hajar Dewantara mengemukakan pendidikan sebagai daya upaya untuk memajukan budi pekerti, pikiran dan fisik seseorang. Ketiga elemen ini tidak bisa berdiri sendiri, melainkan masing-masing saling terkait dan mendukung. Ki Hajar menekankan pentingnya harmoni, yaitu suatu keadaan persatuan yang selaras. (Kembara, 2007, p. 40).

Sementara tokoh yang menerapkan homeschooling lainnya adalah Buya Hamka. Beliau lahir tahun 1908 di Desa Kampung Molek, Meninjau, Sumatera Barat, kemudian meninggal di Jakarta pada 24 Juli 1981. Nama lengkapnya adalah Haji Abdul Malik Karim Amrullah, disingkat menjadi Hamka. Awalan Buya merupakan nama panggilan untuk orang Minangkabau asal katanya abi, abuya bahasa arab yang berarti "ayah kami." Hamka sempat mendapat pendidikan rendah di Sekolah Dasar Maninjau hingga kelas dua. Pada usia 10 tahun, ayahnya mendirikan Sumatera Thawālib di Padang Panjang. Hamka keluar sekolah, lantas mempelajari agama dan mendalami bahasa Arab di Thawālib itu. Hamka adalah seorang otodidak. Dia belajar 
secara mandiri hingga menguasai berbagai bidang ilmu pengetahuan, mulai dari filsafat, sastra, sejarah, sosiologi dan politik (Kembara, 2007, pp. 42-43).

Dalam upaya memberikan layanan terbaik bagi anak-anak, para keluaga homeschooling berusaha memelihara fleksibilitas, baik dalam pemilihan materi ajar maupun metodologi yang digunakan oleh anak-anak untuk mencapai tujuan-tujuan pendidikan yang ingin diraihnya. Ada beberapa kekurangan homeschooling, diantaranya adalah sulitnya memperoleh dukungan atau tempat bertanya, kurangnya tempat sosialisasi, orang tua harus terampil memfasilitasi proses pembelajaran, hingga persoalan berkaitan dengan sistem evaluasi dan penyetaraannya.

Dengan mengutip Sumardiono, Ariefianto memaparkan bahwa di antara kelemahan dalam homeschooling yaitu sosialisasi dengan teman sebaya (horizontal socialization) relatif lebih rendah. Peserta didik homeschooling relatif tidak terekspos dengan pergaulan yang heterogen dan majemuk baik secara sosial dan memungkinkan untuk terisolasi dari lingkungan sosial, khususnya pelaksana homeschooling tunggal dan majemuk. Disamping itu pula dikuatirkan peserta didik dapat kehilangan kesempatan bergaul dengan lingkungan yang heterogen dan majemuk, padahal dalam lingkungan tersebut peserta didik dapat mempelajari banyak hal. Persoalan tersebut berbeda dengan peserta didik yang mengikuti sekolah pada umumnya (Ariefianto, 2017, p. 22).

Adapun diantara kelebihan homeschooling adalah terbentuknya ruangruang kemandirian dan kreatifitas bagi anak, peluang untuk mencapai kompetensi individual secara maksimal, serta dapat terlindung dari penyakit sosial seperti narkoba, kosumerisme, pergaulan menyimpang dan tawuran serta memungkinkan anak siap mengahadapi kehidupan nyata dengan lingkup pergaulan yang lebih luas (Saputra, 2007, pp. 67-72).

Terlepas dari kekurangan dan kelebihannya, sebagai sebuah pola pendidikan alternatif, homeschooling memiliki nilai kemanfaan yang sangat besar. Di antara kemanfaatannya, sistem homeschooling menjadikan anak-anak menjadi subjek belajar. Selama ini ada kesan bahwa di dalam pendidikan formal, peserta didik hanya menjadi objek kurikulum. Dengan kata lain, kegiatan belajar mengajar yang selama ini diselenggarakan bukan menjadikan kurikulum untuk anak, melainkan sebaliknya, yaitu anak sebagai objek kurikulum. Akibatnya, terjadilah kegiatan belajar yang "memaksa" anak untuk menyesuaikan dengan kurikulum.

Idealnya memang kurikulum yang menyesuaikan diri dengan kebutuhan setiap peserta didik. Anak-anak diberi hak untuk memilih kurikulum yang ingin diikutinya. Melalui homeschooling, anak-anak benar-benar di beri peluang untuk menentukan materi-materi yang ingin dipelajarinya. Anak-anak menjadi subjek dalam kegiatan belajar. Bahkan, bukan hanya materi pelajaran yang 
dapat dipilih oleh anak. Dengan menjadikan anak sebagai subjek dalam belajar, belajar yang diselenggarakan anak pun dapat berlangsung secara nyaman dan menyenangkan. Homeschooling dapat dimanfaatkan untuk mengembalikan anak yang semula menjadi objek belajar, menjadi subjek belajar.

Lain pada itu, dalam model Pendidikan homeschooling, objek yang dipelajari sangat luas. Homeschooling akan membawa anak-anak untuk belajar di dunia nyata, di alam yang sangat terbuka. Di samping itu, objek yang dipelajari anak pun bisa sangat luas. Meskipun pada saat ini telah banyak sekolah-sekolah formal yang memanfaatkan alam sebagai medium proses belajar-mengajar, namun ketika anak-anak mulai memasuki pendidikan yang lebih tinggi, mereka pun kembali lagi berhadapan dengan ruang-ruang kelas yang serba kaku dan tertutup. Dengan demikian, homeschooling dapat membebaskan anak untuk belajar apa saja sesuai minat dan hal-hal yang disukai. Sesekali mereka dapat berkunjung ke berbagai tempat yang bisa menjadi objek pelajaran, seperti pesawahan, taman burung, hingga pemandian air panas.

Homeschooling juga dapat menjadi ruang bagi proses menanamkan cinta belajar. Selama ini tak sedikit orang tua yang, karena kesibukannya, cenderung memasrahkan pendidikan anak-anak kepada sekolah-sekolah formal. Tentunya hal ini tidak salah. Namun, kadang-kadang pemasrahan itu disertai juga dengan ketidakpedulian terhadap nasib pendidikan anak-anaknya. Lebih miris, terdapat anggapan umum bahwa belajar hanya dapat dilakukan sebatas di sekolah formal, bukan di tempat yang lebih luas. Homeschooling dapat menyadarkan kepada para orang tua bahwa belajar bisa dilakukan di mana saja, termasuk di rumah. Bahkan, untuk menanamkan rasa cinta belajar kepada anak sejak dini, hanya orang tua yang paling layak untuk mewujudkannya.

Dalam konteks pendidikan informal, penyelenggaraan homeschooling sangatlah fleksibel. Sebagai bentuk dari sistem pendidikan informal, kunci utama penyelenggaraan homeschooling adalah adanya kelenturan atau fleksibilitas. Hal tersebut menuntut suatu model pendidikan yang tidak terlalu kaku dan terstruktur, sebagaimana sekolah formal. Kalau terlalu disusun dalam kurikulum yang baku, maka homeschooling justru akan kehilangan makna utamanya. Itulah sebabnya bagi peserta homeschooling yang semula berasal dari siswa sekolah formal, diperlukan adanya penyesuaian diri yang bertahap.

Selain itu, model homeschooling juga sangat mendukung proses belajar secara kontekstual. Kontekstual sendiri berasal dari kata kerja latin, contexere yang berarti "menjalin bersama." Kata "konteks" merujuk pada "keseluruhan situasi, latar belakang, atau lingkungan" yang berhubungan dengan diri yang terjalin bersamanya. Kita masing-masing berada didalam konteks yang beragam, misalnya, konteks lingkungan tempat tinggal, keluarga, teman- 
teman, sekolah, pekerjaan, kebijakan politik dan ekosistem bumi. Demikian juga, semua identitas yang lain hidup maupun tak hidup berada di dalam sebuah konteks yang khas. Untuk menyadari seluruh potensinya, semua organisme hidup, termasuk manusia, harus berada didalam hubungan yang tepat dengan konteks mereka. Dalam hal ini, homeschooling sangat memungkinkan untuk menampung sekaligus mendukung kegiatan belajar yang kontekstual ini, yakni "ketika seorang anak dapat mengaitkan isi dari mata pelajaran yang sedang dipelajarinya" (Mulyadi, 2007, pp. 44-58).

Konsep Kecerdasan Spiritual

Danah Zohar, dalam bukunya yang berjudul SQ: Spiritual Intelligence, The Ultimate Intelligence, menilai bahwa kecerdasan spiritual merupakan bentuk kecerdasan tertinggi yang memadukan kedua bentuk kecerdasan lainnya, yakni kecerdasan intelektual dan kecerdasan emosional. Kecerdasan spiritual dinilai sebagai kecerdasan yang tertinggi karena erat kaitannya dengan kesadaran seseorang untuk bisa memaknai segala sesuatu dan merupakan jalan untuk bisa merasakan sebuah kebahagiaan. (Zohar \& Marshall, 2000, pp. 3-4).

Orang yang mempunyai kecerdasan spiritual ditandai dengan kemampuan bersikap fleksibel, tingkat kesadaran yang tinggi, kemampuan menghadapi penderitaan, hingga kemampuan menghadapi rasa takut. Hal tersebut dapat membentuk suatu kualitas hidup yang diilhami oleh visi dan nilai. Kecerdasan spiritual dapat mendorong seseorang untuk menghindari kerugian yang tidak perlu, kecenderungan melihat keterkaitan berbagai hal, hingga senantiasa bertanya "mengapa" atau "bagaimana jika." Lain pada itu, kecerdasan spiritual juga dapat membentuk pemimpin yang penuh pengabdian dan bertanggung jawab.

Dalam konteks pendidikan anak, SQ sangatlah penting untuk menopang pertumbuhannya secara seimbang. Dalam Permendikbud No. 137 tahun 2014 Pasal 8 dijelaskan, bahwa pentahapan usia dalam STPPA (Standar Tingkat Pencapaian Perkembangan Anak), dijelaskan bahwa seorang anak berkembang dalam tahapan-tahapannya yang khas. Pada tahap usia lahir-2 tahun, terdiri atas kelompok usia: lahir-3 bulan, 3-6 bulan, 6-9 bulan, 9-12 bulan, 12-18 bulan, 18-24 bulan. Pada tahap usia 2-4 tahun, terdiri atas kelompok usia: 2-3 tahun dan 3-4 tahun. Kemudian pada tahap usia 4-6 tahun, terdiri atas kelompok usia: 4-5 tahun dan 5-6 tahun. Kecerdasan SQ pada anak dapat terrealisasikan pada lingkup perkembangan sesuai tingkat usia anak, meliputi aspek nilai agama dan moral, fisik-motorik, kognitif, bahasa, sosial-emosional dan seni. Lain pada itu, SQ juga berkaitan dengan persoalan nilai agama dan moral yang meliputi kemampuan mengenal nilai agama yang dianut, mengerjakan ibadah, berperilaku jujur, penolong, sopan, hormat, sportif, 
menjaga kebersihan diri dan lingkungan, mengetahui hari besar agama, menghormati dan toleran terhadap agama orang lain.

\section{Metode Penelitian}

Jenis penelitian yang digunakan dalam penelitian ini adalah penelitian kualitatif. Adapun yang dimaksud dengan penelitian kualitatif adalah jenis penelitian yang menghasilkan penemuan-penemuan yang tidak dicapai (diperoleh) dengan menggunakan prosedur-prosedur statistik atau cara-cara lain dari kuantifikasi (pengukuran). Metode penelitian yang digunakan dalam penelitian ini adalah metode deskripsi, yaitu metode yang di maksudkan untuk menyelidiki keadaan, kondisi atau hal-hal lain yang sudah disebutkan yang hasilnya dipaparkan dalam bentuk laporan penelitian (Arikunto, 2013, p. 3).

\section{Hasil Penelitian dan Pembahasan}

Perencanaan Homeschooling di Rumah Negla

Dalam wawancara dengan Rita, salah satu pegiat pendidikan di Rumah Negla, konsep awal yang harus di pahami oleh orang tua adalah anak pada usia 0-7 tahun, sebagaimana dipaparkan dalam ilmu psikologi, mempunyai sifat egosentris, rasa kepemilikan diri sangat kuat dan cenderung melakukan sesuatu berdasarkan kemauannya sendiri atau bisa disebut keras kepala. Hal tersebut sesuai dengan temuan di dalam ilmu psikologi bahwa seorang anak cenderung bersifat egosentris, memiliki rasa ingin tahu secara alamiah, merupakan makhluk sosial, unik, kaya dengan fantasi, memiliki daya perhatian yang pendek dan masa yang paling potensial untuk belajar (Pangastuti, 2014, p. 15)

Berdasarkan hasil wawancara tersebut. tahapan awal yang di lakukan oleh orang tua di keluarga rumah Negla adalah: Pertama, memahami psikologi anak. Hal ini bisa menjadi awal yang baik, karena orang tua akan mengetahui serba-serbi anak, terutama tentang perasaan, kemauan, hingga kondisi jiwanya. Persoalan ini juga diungkapkan Kembara, bahwa tanggung jawab pendidikan anak, baik mental maupun intelektual, berada pada tangan orang tua. Oleh karena itu, orang tua seharusya memahami benar kondisi psikologi, kecenderungan potensi dan bakat anak. Selain itu, orang tua juga harus memetakan kelemahan dan kelebihan anak (Kembara, 2007, p. 66).

Dampak positif perkembangan psikologis anak di lingkungan homeschooling yang membedakan dengan anak sebaya di sekitarnya terletak pada keberaniannya mengungkapkan status dirinya yang tidak bersekolah, terutama ketika teman sebayanya menyinggung hal tersebut. Lain pada itu, seorang anak juga lebih terlihat dewasa dibandingkan teman sebaya yang lainnya. Hal tersebut didorong oleh karena anak yang mendapatkan 
pendidikan homeschooling lebih mendapatkan kasih sayang dan perhatian yang maksimal dari keluarga, khusunya dari kedua orang tua. Di samping itu, anak didik memahami alasan dirinya tidak bersekolah, tidak malu dengan status tidak bersekolah, memahami bakat yang ada dalam dirinya dan megetahui cara mengembangkan bakat tersebut, karena terbiasa mandiri dalam proses pembelajaran.

Kedua, mempelajari metodologi pembelajaran. Hal ini bisa membantu orang tua dalam mengadakan pembelajaran dengan menggunakan metode yang beragam dan disenangi anak. Kak Seto mengungkapkan bahwa homeschooling dapat membebaskan anak untuk belajar apa saja yang sesuai dengan minat dan hal-hal yang disukainya. Sesekali mereka dapat berkunjung ke berbagai tempat yang bisa menjadi objek pelajaran, seperti pesawahan, taman burung, pemandian air panas, kebun binatang, tempat kerja seperti bank, pasar dan masih banyak yang bisa dijadikan tempat belajar (Mulyadi, 2007, pp. 44-58). Kegiatan tersebut membuktikan bahwa orang tua telah mampu mempelajari metodologi pembelajaran yang sesuai, terutama ketika hambatan berupa kebingungan dari diri anak muncul.

Ketiga, orang tua harus sama-sama belajar, karena sejatinya pada saat orang tua mengajak anak untuk belajar, maka pada saat itu pula orang tua ikut belajar. Tak ayal, peran orangtua sebagai fasilitator haruslah orang yang mempunyai kemauan untuk terus belajar (Kembara, 2007, p. 67).

Keempat, kewajiban belajar dimulai pada tingkat pendidikan dasar, bukan pada anak usia dini. Hal ini berkaitan dengan pernyataan yang diungkapkan oleh Ridho, bahwa pada tahun 1960-an, dua orang profesional bidang pendidikan, Ray dan Dorothy Moore mulai melakukan penelitian tentang kesahihan akademis mengenai gerakan pendidikan anak usia dini yang tumbuh begitu pesatnya. Penelitian ini mencakup kajian-kajian independen oleh peneliti lainnya dan ulasan yang bersangkutan dengan pendidikan anak usia dini dan perkembangan fisik dan mental anak. Keduanya menyimpulkan, bahwa sungguh berbahaya memasukkan anak ke sekolah formal bagi anak yang berusia sebelum 8-12 tahun, utamanya laki-laki. Alasannya, karena menghambat karakter kedewasaannya (Ridho, 2017, pp. 90-91). Dengan demikian, pendidikan anak usia dini tidak boleh kaku dan terlalu berstruktur, sebagaimana sekolah formal (Mulyadi, 2007, pp. 44-58).

\section{Pelaksanaan Homeschooling di Rumah Negla}

Berdasarkan hasil wawancara dengan Rita, tipe homeschooling yang digunakan di rumah Negla pada anak usia 0-7 tahun adalah tipe homeschooling tunggal, yaitu format sekolah rumah yang dilaksanakan oleh orang tua dalam satu keluarga yang dalam pelaksanaannya dilakukan secara mandiri. Format sekolah rumah tunggal biasanya dipilih oleh keluarga yang ingin memiliki 
fleksibilitas maksimal dalam penyelenggaraan homeschooling. Mereka bertanggung jawab sepenuhnya atas seluruh proses yang ada dalam homeschooling, mulai perencanaan, pelaksanaan, evaluasi, pengadministrasian, hingga penyediaan sarana pendidikan (Sumardiono, 2007, p. 60).

Tahap selanjutnya, sebagaimana dipaparkan Rita, merumuskan kurikulum dan program homeschooling. Kurikulum yang digunakan di Rumah Negla adalah konsep fitrah berbasis pendidikan. Hal tersebut berpijak pada pemahaman bahwa anak-anak, bahkan sejak berada dalam kandungan, sudah memiliki hasrat untuk belajar (Mulyadi, 2007, p. 100). Pada usia 0-7 tahun, fitrah keimanan seorang anak harus dikuatkan dengan merangsang kecintaan pada ibadah, sehingga memberikan kesan positif dalam beribadah.

Menurut Rita, program pendidikan yang dilakukan di Rumah Negla terdiri dari program terstruktur dan program tidak terstruktur. Dalam hal program tidak terstruktur atau informal, model pendidikan anak usia 0-7 tahun lebih menekankan bukan pada bagaimana membentuk struktur pendidikan yang formal sesuai dengan kurikulum yang baku, melainkan upaya menstrukturasi pengalaman anak. Sementara program terstrukutur tahun terdiri dari meliputi rutinitas-rutinitas keseharian. Diantaranya, membiasakan bangun pagi untuk segera melaksanakan aktifitas yang berkaitan dengan ritual ibadah. Namun demikian, anak yang masih berusia di bawah 7 tahun lebih ditekankan pada persoalan adab, sehingga shalat belum dipelajari secara ketat, melainkan pembelajarannya lebih tertuju pada bagaimana menumbuhkan kecintaan kepada Allah Swt. Di Rumah Negla, kebiasaan bangun subuh tersebut di pertahankan sejak usia dini, sehingga saat seorang anak menginjak usia 7 tahun, usia yang memadai untuk sebagai masa latih ritual-ritual keagamaan, anak sudah terbiasa melaksanakannya.

Salah satu program yang dilaksanakan di Rumah Negla adalah pengajaran terkait doa-doa yang aplikatif. Doa-doa aplikatif adalah doa yang sering anak lakukan sebelum atau sesudah melaksanakan rutinitas kegiatannya, seperti doa sebelum makan, doa sebelum tidur. Mempertimbangkan kegiatan tersebut konsisten dilakukan dalam satu hari, maka pembiasaan tersebut menjadikan anak akan terbiasa membacanya, sehingga lebih cepat dalam proses penghapalannya.

Selain doa-doa, anak didik di Rumah Negla juga diberikan kegiatankegiatan yang dapat merangsang aspek motorik kasar dan motorik halusnya. Motorik kasar yang dimaksud adalah aktifitas berlari, duduk, menaiki tangga, melewati jembatan dan aktifitas-aktifitas lainnya. Orang tua diharapkan bisa merangsang anak melakukan motorik kasar dan bisa melakukannya tanpa dibimbing. Misalnya, anak akan mengetahui bagaimana rasanya melewati jembatan kecil pada jalan menuju sawah ketika anak sudah melakukannya 
dengan didampingi orang tua. Sedangkan untuk contoh motorik halus adalah anak akan mengetahui bagaimana rasanya terkena pisau tajam ketika belajar mengupas bawang di dapur, maka pada hal ini orang tua diharapkan bisa merangsang anak untuk tertarik masuk ke dapur.

Menurut Rita, menumbuhkan dan mengembangkan kecerdasan spiritual membutuhkan proses yang lebih panjang dan menuntut kesabaran yang tinggi dibandingkan dengan kecerdasan intelektual, sehingga rumah adalah tempat yang paling cocok untuk anak usia dini melewati proses itu. Oleh sebab itu, cara paling efektif untuk mengembangkan kecerdasan spiritual pada anak di Rumah Negla adalah melibatkan anak dalam setiap kegiatan ibadah, sehingga anak meraskan pengalaman spiritual secara langsung, bukan hanya pemahamannya melalui teori. Apabila anak sejak usia dini sudah dilibatkan dalam beribadah, kecerdasan spiritualnya akan terasah dengan baik. Sebab, didalam setiap bentuk ibadah selalu terikat dengan keyakinan yang tidak kasat mata, yakni keimanan. Maka, kekuatan dari keimananlah yang membuat seseorang bisa mempunyai kecerdasan spiritual yang luar biasa (Azzet, 2010, pp. 65-67).

\section{Kelebihan dan Kekurangan Homeschooling di Rumah Negla}

Berdasarkan hasil wawancara dengan Rita, salah satu pegiat homeschooling, kelebihan dari homeschooling di Rumah Negla terletak pada kelekatan orang tua bersama anak sangat dekat. Kebersamaan tersebut akan memberi dampak positif antara hubungan orang tua dengan anak. Sementara dari sisi pembiayaan, homeschooling di Rumah Negla berbiaya lebih murah. Mengingat orang tua berperan sebagai pengelola, maka segala sesuatu pembiayaan bisa diminimalisir dengan angka yang lebih murah. Misalnya, dengan spontan mengajak anak berjalan mengelilingi kampung, maka pembelajaran sudah dilaksanakan tanpa harus mengeluarkan biaya transportasi.

Dengan menjadikan rumah sebagai basis pengembangan pendidikan anak, maka nilai kekeluargaan akan lebih kuat. Perbedaan nilai-nilai yang diajarkan keluarga dengan sekolah merupakan salah satu alasan orangtua memilih homeschooling, khususnya nilai-nilai kesopanan, nilai moral dan lainlain. Karena jika sudah ada perbedaan, maka membutuhkan waktu lama untuk memperbaikinya. Dari banyak pengalaman yang sudah dilewati, maka nilai keluarga akan kalah dengan nilai yang ditanamkan sekolah, karena anak lebih banyak menghabiskan waktunya di sekolah. Misalnya, di rumah anak diajarkan untuk peduli kebersihan lingkungan dengan disiplin membuang sampah pada tempatnya, maka ketika anak berada di sekolah, orang tua tidak bisa menjamin anak tetap peduli kebersihan atau sebaliknya. Dengan adanya homeschooling, orangtua lebih leluasa mendisiplinkan anak dalam hal apapun. 
Selain dari kontrol yang lebih fleksibel, model homeschooling juga lebih bisa maksimal proses menyiapkan anak untuk fase selanjutnya, yaitu fase sosial. Lingkungan keluarga sangatlah besar pengaruhnya bagi perkembangan sosial anak, khususnya anak usia 0-7 tahun. Karena pada usia tersebut anak diibaratkan seperti spons; menyerap berbagai fakta, hingga perilaku dari orang yang ada di sekitarnya. Maka homeschooling dipandang bisa maksimal dalam menyiapkan anak untuk fase sosial, karena jika anak tidak memiliki fondasi pendidikan dan kebiasan positif yang kuat di keluarga, maka anak akan lebih mudah terpengaruh oleh lingkungan luar.

Lain pada itu, model homeschooling juga menyediakan waktu yang fleksibel untuk lebih mengasah spiritual orang tua. Orang tua menjadi lebih sabar dan bersyukur dengan proses pembelajaran anak yang menjadi tanggung jawabnya. Ketika orang tua (pengajar) tidak maksimal dalam mengajarkan kesabaran ketika proses mendidik anak, khususnya dalam pembelajaran homeschooling, maka kecerdasan spiritual anak tidak akan muncul secara maksimal

Terlepas dari beberapa kelebihan $\mathrm{di}$ atas, model pembelajaran homeschooling juga memiliki beberapa kekurangan mendasar. Diantaranya adalah pandangan negatif dari masyarakat sekitar Rumah Negla. Hal ini di dukung dengan hasil wawancara yang dilakukan peneliti dengan ibu RT, Rahma (36 tahun) dan Eni (56 tahun). Menurut Rahma, anak-anak di Rumah Negla kurang bersosialisasi dengan teman sebaya di lingkungan rumahnya, karena saat anak bermain beberapa menit, sang anak sudah dipanggil oleh orang tuanya.

Sementara mengenai kecerdasan spiritual, anak-anak di Rumah Negla dipandang positif karena didukung oleh orang tua yang paham agama. Hal tersebut terlihat dari kesopanan dan keramahan mereka ketika bertemu dengan orang lain. Hanya saja, Rahma tidak begitu paham dengan model yang dikembangkan, karena memang terbilang baru menemukan bahwa ada keluarga yang tidak menyekolahkan anak. Rahma sering melihat bahwa meskipun keluarga Rumah Negla bermain di sawah, di kebun, namun tetap saja tidak logis jika dinamakan dengan sekolah. Rahma juga sering melihat bahwa anak bungsu dari keluarga Rumah Negla yang bernama Fadlah mengamuk ingin pergi sekolah. Ketika awal-awal Rumah Negla berdiri, banyak masyarakat yang mengadu kepada RT tentang kebijakan Rumah Negla yang di pandang aneh dan tidak masuk akal. 


\section{Kesimpulan}

Perencanaan Homeschooling dalam mengembangkan kecerdasan spiritual pada anak usia 0-7 tahun di rumah Negla dilakukan denga terlebih dahulu memahami psikologi anak. Hal ini bisa menjadi awal yang baik, karena orang tua akan mengetahui serba-serbi anak, terutama tentang perasaan, kemauan dan hakikat jiwanya. Homeschooling di Rumah Negla menuntut keterlibatan orang tua yang harus sama-sama belajar. Karena pada saat orang tua mengajak anak untuk belajar, maka pada saat itu pula orang tua ikut belajar, yakni dengan memahami bahwa wajib belajar sebenarnya pada tingkat pendidikan dasar bukan pada usia dini.

Pelaksanaan Homeschooling dalam mengembangkan kecerdasan spiritual di Rumah Negla dilakukan pada anak usia 0-7 tahun. Pada usia 0-7 tahun, fitrah keimanannya harus dikuatkan dengan merangsang kecintaan pada ibadah, serta memberikan kesan positif dalam beribadah. Rumah Negla sendiri memiliki program terencana dan program tidak terencana. Dalam konteks program tidak terrencana, program yang digunakan adalah pendidikan yang tidak terstruktur, melainkan upaya menstrukturisasi pengalaman anak. Sementara program terstrukutur di Rumah Negla untuk usia 0-7 tahun terdiri dari membiasakan bangun pagi, mengajarkan doa-doa yang aplikatif, hingga merangsang motorik kasar dan motorik halus. Kelebihan homeschooling dalam mengembangkan kecerdasan spiritual di Rumah Negla terletak pada pembasisan kelekatan orang tua bersama anak. Dengan menyiapkan potensi spiritual pada anak, maka orang tua dapat maksimal dalam proses menyiapkan anak untuk fase selanjutnya, yaitu fase sosial. Sementara kekurangan dari homeschooling adalah ketika orang tua tidak sabar, tidak mau belajar maka tidak akan lebih baik secara spiritual terhadap anak. Adapaun secara sosial, Rumah Negla kurang memberikan respon secara positif, dikarenakan masyarakat masih memandang belajar hanya bisa dilakukan di sekolah. Anak yang tidak bersekolah formal dianggap tidak belajar. Hal ini tentu berbeda dengan pandangan yang berkembang pada orang tua pegiat Rumah Negla yang memandang bahwa belajar bisa kapan dan di mana saja, serta tidak terkekang oleh waktu.

\section{DAFTAR PUSTAKA}

Ariefianto, L. (2017). Homeschooling: Persepsi, Latar Belakang dan Problematikanya. Jurnal Edukasi, 21-26.

Arifin, M. (2003). Filsafat Pendidikan Islam. Jakarta: PT Bumi Aksara. 
Arikunto, S. (2013). Prosedur Penelitian: Suatu Pendekatan Praktek. Jakarta: PT Rineka Cipta.

Azzet, A. M. (2010). Mengembangkan Kecerdasan Spiritual bagi Anak. Yogyakarta: Katahati.

Dictionary, T. F. (2018, August 20). Thefreedictionary.com/homeschool. Retrieved from Thefreedictionary.com: http://www. Thefreedictionary.com/homeschool

Ismail, M. I. (2016). Homeschooling: Sebuah Pendidikan Alternatif. Lentera Pendidikan, 100-111.

Kembara, M. (2007). Panduang Lengkap Homeschooling. Bandung: Progressio.

Mulyadi, S. (2007). Homeschooling Keluarga Kak Seto. Bandung: Mizan Pustaka.

Pangastuti, R. (2014). Edutaintment PAUD. Yogyakarta: Pustaka Pelajar.

Ridho, M. (2017). Catatan Kuliah Homeschooling dan Pendidikan Islam. Bogor: KM Publishing.

Saputra, A. A. (2007). Rumahku Sekolahku. Yogyakarta: Graha Pustaka.

Sumardiono. (2007). Homeschooling: Lompatan Cara Belajar. Jakarta: PT Elex Media Komputindo.

Zohar, D., \& Marshall, I. (2000). SQ: Kecerdasan Spiritual. (R. Astuti, A. N. Burhani, $\&$ A. Baiquni, Trans.) Bandung: Mizan. 
